\title{
High-Performance Work Systems And Firm Performance: Moderating Effects Of Organizational Communication
}

\author{
Gyeonghwan Lee, Sogang University, South Korea \\ Myeongju Lee, Sogang University, South Korea \\ Yoonhwan Sohn, Sogang University, South Korea
}

\begin{abstract}
This study examines the relationship between high-performance work systems (HPWS) and organizational performance and how the relationship differs by type of communication within organizations. Using data on publicly traded manufacturing firms in Korea from the Human Capital Corporate Panel survey, we find that HPWS are positively related to organizational performance, and importantly, this relationship varies by the level of vertical and horizontal communication. The positive effect of HPWS on organizational performance is more apparent when vertical and horizontal communications are relatively high. These results emphasize the role of internal communication as an important organizational context for the implementation of HPWS.
\end{abstract}

Keyword: High-Performance Work System; Organizational Communication; Vertical Communication; Horizontal Communication

\section{INTRODUCTION}

$7 \mathrm{n}$ recent years, the literature on strategic human resource management (SHRM) has attracted growing interest (Batt, 2002; Boxall \& Macky, 2007). The main strand of this literature investigates the association between high-performance work systems (HPWS) and organizational performance (e.g.,
Arthur, 1994; Batt, 2002; Huselid, 1995; Liao, Toya, Lepak, \& Hong, 2009). In these studies, researchers regard HPWS as a bundle of HR practices designed to improve employees' abilities, motivation, and participation opportunities, thereby increasing job satisfaction, organizational commitment, and organizational performance (Huselid 1995; Jiang, Lepak, Hu, \& Baer, 2012; Wright \& McMahan, 1992). Prior studies generally show a positive HPWS-organizational performance relationship (e.g., Arthur, 1994; Huselid, 1995), but several researchers challenge the validity of these findings (e.g., Wright, Gardner, Moynihan, \& Allen, 2005). Controlling for organizational performance over the previous year, Wright et al. (2005) find a decreasing positive HPWSorganizational performance relationship. Consistent with Wright et al. (2005), several scholars argue that the HPWS-organizational performance relationship is more complex than assumed (e.g., Wall \& Wood, 2005; Wright $\&$ Gardner, 2003). These mixed findings can be attributed to the lack of both theoretical and empirical research showing clear mechanisms explaining the HPWS-organizational performance relationship (Delery, 1998; Wright \& Gardner, 2003). Many prior studies pay attention to individual and organizational moderating factors in the HPWSorganizational performance relationship, such as firm strategies (Bae \& Lawler, 2000; Snell \& Youndt, 1995), industry (Batt, 2002), and union representation (Cooke, 1994). However, it is still recommended that scholars explore other organizational contexts that might moderate the HPWS-organizational performance relationship (Lau \& Ngo, 2004; Lertxundi \& Landeta, 2011).

The present study proposes that organizational communication is an important situational factor that might influence the relationship between HPWS and organizational performance. Earlier studies acknowledge that effective organizational communication leads to employee satisfaction and perceptions of interpersonal and informational justice (Madlock, 2008; Kernan \& Hanges, 2002), but insufficient attention is paid to organizational communication in the HPWS literature (Bowen \& Ostroff, 2004). For HPWS design and implementation, the advantages of 
organizational communication are apparent. Theoretically, HPWS should be designed to support organizational strategy and convey organizational information to employees (Bretz \& Judge, 1994), but often, these intended purposes cannot be easily achieved (Legge, 2005) due to the gap between the intended and the implemented HPWS. Organizational communication can reduce this gap by facilitating information sharing, voluntary coordination, and cooperation (e.g., Den Hartog, Boon, Verburg, \& Croon, 2013). Therefore, we suggest that organizational communication are essential to appropriately design and implement HPWS and that the effectiveness of HPWS depends on the level of organizational communication. Moreover, we divide organizational communication into vertical and horizontal communication and argue that these two types of organizational communication have positive moderating effects on the HPWS-organizational performance relationship.

To test these hypotheses, we use data on the HPWS of Korean manufacturing firms from the Human Capital Corporate Panel (HCCP) survey and find overall support for our hypotheses. We demonstrate that a high level of HPWS is positively associated with firm performance, and this positive relationship is more pronounced when the levels of vertical and horizontal communication are high. Thus, our results indicate that organizational communication is an important organizational factor moderating the HPWS-organizational performance relationship. Our study contributes to the HPWS and communication literature by illustrating how internal communication can be an important organizational context in designing and implementing organizational systems.

\section{THEORY AND HYPOTHESES}

\section{HPWS and Organizational Performance}

SHRM research shows that the use of HPWS is associated with positive organizational level outcomes, such as lower turnover (Batt, 2002) and greater commitment (Gong, Law, Chang, \& Xin, 2009), productivity and quality (MacDuffie, 1995), and organizational financial performance (Huselid, 1995). Among these studies, research on the HPWS-financial performance relationship argues that HPWS affect financial performance by simultaneously providing employees with opportunities to contribute to the organization's success, motivating them to perform well, and increasing labor force ability (Huselid, 1995; MacDuffie, 1995; Jiang et al. 2012). This argument is based on the idea that the effects of HPWS might work through employees.

Two perspectives explain how HPWS translates into organizational performance through employees: the behavioral perspective and the human capital/resource-based perspective. From the behavioral perspective, HPWS affect organizational outcomes by influencing employee behaviors; more specifically, if HPWS encourage employees to act in ways consistent with company goals, performance improves. Therefore, employees should be motivated and empowered to contribute to organizational performance. Related human resource (HR) practices include developmental performance management, competitive compensation, incentives, rewards, extensive benefits, promotions, career development, and job security (Jiang et al. 2012). The human capital/resource-based perspective focuses on the potential contributions of employees' competencies, that is, their knowledge, skills, and abilities. According to this perspective, firms should secure knowledgeable, skillful, experienced employees through education and training in order to acquire human capital with competitive advantages (Subramaniam \& Youndt, 2005). This goal can be achieved through HR practices such as comprehensive recruitment, rigorous selection, extensive training, flexible job design, work teams, employee involvement, and information sharing (Jiang et al. 2012). These two perspectives explain how HPWS affect organizational performance and highlight the crucial roles of employee behaviors and attitudes in translating HPWS into performance. Therefore, we propose the following baseline hypothesis:

Hypothesis 1: HPWS are positively related to organizational performance.

\section{Role of Communication}

The importance of organizational communication is extensively discussed in the literature (Rogers \& AgarwalaRogers, 1976). Organizational communications generally provides employees with accurate organizational information and opportunities to affect organizational decision-making processes (Kernan \& Hanges, 2002). Thus, organizational communication reduces the uncertainty related to employees' tasks. Consequently, prior studies show 
that the effective communication can lead to positive employee-level outcomes (Madlock, 2008; Kernan \& Hanges, 2002). Madlock (2008) reports that managers' communication competency is related to employee satisfaction. In addition, Kernan and Hanges (2002) suggest that high-quality communication positively influences employees' perceptions of interpersonal and informational justice in organizations.

Several SHRM studies also emphasize the role of communication in organizations, but the field neglects organizational communication (Bowen \& Ostroff, 2004). Organizational communication allows employees to receive precise task and organizational information and increase their understanding of their tasks and expected roles, the organization's policies and practices, and reasons underlying organizational decisions and enacted procedures (Kernan \& Hanges, 2002). In HPWS, active communication clarifies employees' understandings of HR and related practices (Den Hartog et al. 2013). Moreover, communication with managers and other workers enables employees to affect the organizational decision-making process (Kernan \& Hanges, 2002) and facilitates voluntary cooperation and coordination (Robbins \& Judge, 2013). Therefore, Nishii and Wright (2008) suggest that appropriate communication is a necessary condition for HR practices to have the intended effects on employees.

While the quality of organizational communication can differ by organization, more importantly, each organization might emphasize different aspects of organizational communication. Based on information flow, organizational communication can be divided into vertical and horizontal communication (Simpson, 1959; Rodriguez, 2005). We first argue that vertical communication positively moderates the HPWS-organizational performance relationship by reducing the gap between the intended and the implemented HPWS through bilateral communication between employees and managers. Vertical communication can be classified as top-down and bottom-up communication. Top-down communication flows down from an upper level of an organization to a lower level. Supervisors use this type of communication to assign goals, provide task instructions, explain practices and procedures, comment on problems that need attention, and offer feedback to employees (Robbins \& Judge, 2013). A clear advantage of topdown communication is that employees in organizations that communicate precise, adequate, consistent HR messages to their employees are more likely to understand the intended HPWS (Den Hartog et al. 2013), which is essential for employees to know which behaviors are expected and rewarded in the HPWS. This clear understanding of the event-effect relationship is an important condition for HPWS to affect employees' behaviors (Bowen \& Ostroff, 2004). Bottom-up communication is the upward flow of information from a lower level in an organization to a higher level. This type of communication is used by employees to provide feedback to supervisors and inform them of any problems and the employees' progress toward goals. Supervisors also use bottom-up communication to obtain ideas on how to improve conditions (Robbins \& Judge, 2013). Consequently, bottom-up communication allows managers to develop and revise HR practices that more accurately reflect employees' needs and opinions. When employees believe that the organization supports employees, they are more likely to perceive incentives, welfare, and promotions as forms of recognition for their contributions (Allen, Shore, \& Griffeth, 2003) and, thus, invest greater efforts toward achieving the organization's goals. We argue that active vertical communication creates organizational conditions that, first, strengthen the effects of HPWS on organizational performance by reducing the gap between the intended and implemented HPWS and, second, increase employee motivation and participation. Therefore, we propose the following hypothesis:

Hypothesis 2.1: Vertical communication positively moderates the relationship between HPWS and organizational performance such that the relationship between HPWS and organizational performance is stronger when vertical communication is high.

Whereas vertical communication occurs between employees at different levels of the organization, horizontal communication occurs among employees at the same level within the same department and across departments (Simpson, 1959). We argue that horizontal communication positively moderates the HPWS-organizational performance relationship by facilitating corporation and coordination between employees through improved mutual understanding of their expected roles and responsibilities.

All organizations are to some extent vertically and horizontally differentiated, which gives rise to coordination and cooperation issues. Organizations generally have specialized policies and functions to deal with these issues, but their effects are often limited as a result of insufficient consideration of others' expected roles and responsibilities. This misunderstanding is also a critical obstacle to the effective implementation of HPWS. One of the important 
characteristic of HPWS is that they are designed to facilitate cooperation and inter- and intra-department coordination among employees (Jiang el al. 2012), but this potential cannot be successfully realized if employees do not have clear understandings of each other's roles. As well, even skillful, knowledgeable employees cannot assist others without clear understandings of their needs. Horizontal communication among employees can help overcome this problem by providing a basis for participation and idea exchanges among employees (Schermerhorn, Osborn, Uhl-Bien, \& Hunt, 2012). Horizontal communication can also save time for mutual adjustments, thereby facilitating coordination (Robbins \& Judge, 2013). Under these conditions, employees are more likely to engage in task-related problem-solving processes with other employees and more aggressively expand their activities beyond their own tasks while voluntarily making mutual adjustments. Therefore, we argue that strong horizontal communication creates an organizational context that strengthens the HPWS-organizational performance relationship. We propose the following hypothesis:

Hypothesis 2.2: Horizontal communication positively moderates the relationship between HPWS and organizational performances such that the relationship between HPWS and organizational performance is stronger when horizontal communication is high.

\section{METHODS}

\section{Sample and Data Collection}

To test the hypotheses, we use data from the HCCP survey conducted by the Korea Research Institute of Vocational Education and Training, a government-funded non-profit research institute. The HCCP survey, administrated once every two years since 2005, is aimed at understanding firms' human-capital and human-resource-building efforts and their impacts on organizational performance. The survey includes information on business characteristics, human resources management (HRM) practices, human capital characteristics, and organizational performance. Trained interviewers conduct face-to-face interviews with multiple employees and managers in various departments including strategic planning and HR departments. All the firms targeted by the survey are in Korea and have at least 100 employees.

For our study, we examine all the publicly traded manufacturing firms in the third (2009) and fourth (2011) waves of the survey. We select this time period for two reasons. First, the Korean government adopted the Korean Standard Industrial Classification-9 (KSIC-9) in 2008. The HCCP modified its sampling frame and process in response, so we do not use data from the first and second waves conducted before the change. Second, organizational financial performance, our dependent variable which is measured at time $t_{+1}$, is not available in the fifth wave. After excluding firm-year observations with missing information from the initial sample of 441 firm-year observations (226 firms in 2009 and 215 firms in 2011), the final sample includes 403 firm-year observations (222 firms in 2009 and 181 firms in 2011).

\section{Measures}

\section{Dependent Variable}

Organizational performance can be measured using various methods. Following previous studies, we select return on assets (ROA) as our measure (Wright et al. 2005). ROA is a frequently used organizational performance measure in the HPWS studies. As well, a high level of HPWS is associated with both benefits and costs, so it is appropriate to use measures that include costs side effects to examine the impact of HPWS on organizational performance (Zatzick $\&$ Iverson, 2006). Therefore, we use ROA at time $t_{+1}$ to measure organizational performance.

\section{Independent Variables}

To construct the HPWS variable, we use the HCCP survey data from HR managers. Amid heated debate on the best way to measure HPWS, the most frequently used approach is an additive measure (Chadwick, 2010). This approach assumes that the effectiveness of an HR system increases with the number of substitutable HR practices. Despite this assumption, this approach is the most appropriate for HCCP data because the survey has consistently included 
questions about the existence of HR practices since the first wave. Based on an extensive review of the HPWS literature, we select $14 \mathrm{HR}$ practices that improve employees' abilities, motivation, and participation (Jiang el al. 2012): external training arrangements, flexible job assignments, evaluation feedback, individual incentives, profits sharing, mentoring or coaching, career development plans, internal contest programs, suggestion programs, quality circle, total quality control program, knowledge sharing program, management by objectives, and financial support for external training. Based on this list, the number of HR practices that a focal firm adopted in each year is used as a HPWS measure. This variable is measured at time $t$.

\section{Moderator Variables}

Given the information flow of communication, we classify communications into two types: vertical and horizontal communication. Employees are asked to rate three items regarding the effectiveness of internal communication effectiveness using a 5-point Likert scale $(1=$ absolutely disagree; $5=$ absolutely agree). The three items are: "Our company gives employees detailed information on firm strategy and financial performance," "We can freely suggest ideas to supervisors," and "We can communicate well with other members of other teams." Using these items, we measure the effectiveness of the two types of internal communications. The first two items are averaged to measure vertical communication, and the last item is used to measure horizontal communication. We aggregate employees' responses to the organizational level for analysis, so we check for interrater agreement and reliability. The results indicate a moderate but acceptable level of agreement (vertical communication: $\mathrm{r}_{\mathrm{WG}}>.745$; horizontal communication: $\left.\mathrm{r}_{\mathrm{WG}}>.694\right)$ and significant organizational level effects (vertical communication: $\mathrm{ICC}(1)>.140$, $\operatorname{ICC}(2)>.778, F$-value < .000; horizontal communication: $\operatorname{ICC}(1)>.100, \operatorname{ICC}(2)>.705, F$-value $<.000)($ LeBreton $\&$ Senter, 2008).

\section{Control Variables}

We control for firm size, firm age, union presence, HR department presence, prior organizational performance, leverage, current ratio, market demand conditions, job satisfaction, and organizational commitment, which can all affect organizational performance. In addition, we include industry membership and year dummies. Firm size is measured using the natural logarithm of total assets, and firm age is measured by the number of years since the founding of the firm. Firm size and age are log-transformed. HR department presence is included to partially control for the effect of its specialized role and takes the value of 1 if the firm has a specialized HR department and 0 otherwise. Union presence is included to account for unions' role in implementing HPWS and effects on organizational performance. This variable takes the value of 1 if the firm has a specialized HR department and 0 otherwise. Leverage and current ratio are included to account for firms' financial distress. Leverage is measured by dividing the firm's total debt by equity, and current ratio is measured by dividing the current assets by the current debt. Prior organizational performance, measured by ROA, is included to mitigate the influence of prior organizational performance on HPWS and organizational performance. Demand condition is measured using an item asking managers to evaluate changes in the demand condition of major products or services over the past two years using a 5 -point Likert-type scale $(1=$ strongly decrease; $5=$ strongly increase). Job satisfaction is measured using the aggregated score of three items from the employee survey: "I'm satisfied with the work I'm doing," "I'm satisfied with my salary," and "I'm satisfied with the relationship with other employees." These items are measured on a Likert-type scale $\left(1=\right.$ absolutely disagree; $5=$ absolutely agree $\left(\mathrm{r}_{\mathrm{WG}}>.825\right.$, ICC $(1)>.171$, ICC $(2)>.8166$, Fvalue $<.000$ ). Organizational commitment is measured using the aggregated score of four items from the employee survey: "I will consider leaving the firm if another firm offers better conditions," "I regard the problems of the firm as my problems," "I will lose many things in my life if I decide to leave the firm," and "Devoting myself to the firm is worth it." These items are also measured on a Likert-type scale ( $1=$ absolutely disagree; $5=$ absolutely agree $)$ $\left(\mathrm{r}_{\mathrm{WG}}>.903, \operatorname{ICC}(1)>.092\right.$, ICC $(2)>.686, \mathrm{~F}$-value $\left.<.000\right)$. Year dummies are also included to account for time effects. All the control variables are measured at time $t$.

\section{Analysis}

The final sample contains data from two waves. In this case, ordinary lease squares (OLS) regression is not appropriate because without considering unobserved firm-level heterogeneity, the results would be biased and inconsistent. In modeling unobserved firm-level heterogeneity, the fixed-effect model is preferred because it can 
control for all the time-invariant firm-specific effects without losing the degree of freedom (Green, 2003). To confirm the suitability of using fixed-effect model, we perform the Hausman tests. The results are significant for all equations, indicating that fixed effects model is appropriate (Hausman \& Taylor, 1981). In addition, F-tests assessing the joint significance of firm-specific effects suggest the presence of firm-specific effects.

\section{RESULTS}

Table 1 presents the descriptive statistics and bivariate correlations for the study variables. To examine for multicollinearity issues, we calculate the variance inflation factors (VIF). VIFs are not available in fixed effects regression, so we generate them after running OLS regressions using within-transformed variables. The largest VIF is less than the recommended cutoff of 10 , indicating that multicollinearity is not a serious problem in our analysis (Chatterjee, Hadi, \& Price, 2000).

Table 1. Means, Standard Deviations, and Correlations

\begin{tabular}{l|l|c|c|c|c|c|c|c|c}
\hline No. & \multicolumn{1}{|c}{ Variables } & Mean & S.D. & $\mathbf{1}$ & $\mathbf{2}$ & $\mathbf{3}$ & $\mathbf{5}$ & $\mathbf{6}$ \\
\hline 1 & Organizational performance & 0.016 & 0.134 & & & & & \\
\hline 2 & Prior Organizational performance & 0.013 & 0.176 & $0.549^{* *}$ & & & & \\
\hline 3 & Firm Size & 19.216 & 1.357 & $0.175^{* *}$ & $0.187^{* *}$ & & & \\
\hline 4 & Firm Age & 36.298 & 17.442 & 0.045 & 0.038 & $0.300^{* *}$ & & \\
\hline 5 & Union Presence & 0.931 & 0.255 & 0.002 & -0.003 & $0.150^{* *}$ & $0.186^{* *}$ & \\
\hline 6 & HR Department & 0.707 & 0.456 & $0.108^{*}$ & 0.054 & $0.293^{* *}$ & -0.018 & 0.060 & \\
\hline 7 & Leverage & 1.292 & 1.985 & $-0.222^{* *}$ & $-0.199^{* *}$ & 0.070 & -0.010 & -0.031 \\
\hline 8 & Current Ratio & 1.869 & 1.827 & $0.179^{* *}$ & $0.156^{* *}$ & $-0.114^{*}$ & $-0.085+$ & 0.041 & -0.059 \\
\hline 9 & Changes in Demand Conditions & 3.295 & 1.022 & $0.113^{*}$ & 0.052 & $0.114^{*}$ & -0.025 & 0.069 & 0.074 \\
\hline 10 & Organizational Commitment & 3.403 & 0.363 & $0.150^{* *}$ & $0.142^{* *}$ & $0.430^{* *}$ & $0.219^{* *}$ & $0.111^{*}$ & $0.147^{* *}$ \\
\hline 11 & Job Satisfaction & 3.552 & 0.345 & $0.171^{* *}$ & $0.154^{* *}$ & $0.404^{* *}$ & $0.182^{* *}$ & $0.119^{*}$ & $0.195^{* *}$ \\
\hline 12 & HPWS & 6.583 & 3.016 & $0.199^{* *}$ & $0.152^{* *}$ & $0.412^{* *}$ & -0.015 & $0.150^{* *}$ & $0.421^{*-1}$ \\
\hline 14 & Vertical Communication & 3.375 & 0.389 & $0.117^{*}$ & $0.086+$ & $0.263^{* *}$ & -0.022 & 0.061 & $0.178^{* *}$ \\
\hline 15 & Horizontal Communication & 3.334 & 0.388 & 0.013 & 0.011 & $0.157^{* *}$ & 0.016 & $0.083+$ & 0.022 \\
\hline
\end{tabular}

\begin{tabular}{|c|c|c|c|c|c|c|c|c|c|c|}
\hline No. & Variables & Mean & S.D. & 7 & 8 & 9 & 10 & 11 & 12 & 13 \\
\hline 7 & Leverage & 1.292 & 1.985 & & & & & & & \\
\hline 8 & Current Ratio & 1.869 & 1.827 & $-0.260^{* *}$ & & & & & & \\
\hline 9 & Changes in Demand Conditions & 3.295 & 1.022 & -0.018 & 0.012 & & & & & \\
\hline 10 & Organizational Commitment & 3.403 & 0.363 & -0.022 & $0.086+$ & $0.130^{* *}$ & & & & \\
\hline 11 & Job Satisfaction & 3.552 & 0.345 & -0.069 & 0.075 & $0.163^{* *}$ & $0.739^{* *}$ & & & \\
\hline 12 & HPWS & 6.583 & 3.016 & 0.008 & 0.032 & 0.059 & $0.305^{* *}$ & $0.319^{* *}$ & & \\
\hline 14 & Vertical Communication & 3.375 & 0.389 & -0.079 & 0.063 & $0.138^{* *}$ & $0.488^{* *}$ & $0.542^{* *}$ & $0.327^{* *}$ & \\
\hline 15 & Horizontal Communication & 3.334 & 0.388 & -0.048 & 0.009 & 0.036 & $0.451^{* *}$ & $0.499^{* *}$ & $0.137^{* *}$ & $0.623^{* *}$ \\
\hline
\end{tabular}

Note. $N=403 ;+p<.10,{ }^{*} p<.05,{ }^{* *} p<.01, * * * p<.001$; two-tailed

Table 2 summarizes the results of the fixed-effects regression analysis of the effects of HPWS on organizational performance and the moderation effects of communication. Model 1 in Table 2 includes the control variables, while model 2 includes the control variables for the main effect of HPWS. Models 4 and 6 include the control variables, main effects, and interaction terms. Chi-square statistics indicate that all the models are significant.

In hypothesis 1, we argue that HPWS is positively related to organizational performance. As shown in models 2-6 in Table 2, hypothesis 1 is supported. For example, in model 1, the estimated coefficient of HPWS is positive and significant $(\beta=.011, p \leq .05)$, providing support for hypothesis 1 . The effects of HPWS are stable across all the models. 
Table 2. HPWS and Organizational Performance

\begin{tabular}{|c|c|c|c|c|c|c|}
\hline & Model 1 & Model 2 & Model 3 & Model 4 & Model 5 & Model 6 \\
\hline \multirow{2}{*}{ Constant } & -0.825 & -0.722 & -0.894 & -1.103 & -0.783 & -1.111 \\
\hline & $(1.218)$ & $(1.205)$ & $(1.206)$ & $(1.190)$ & $(1.201)$ & $(1.185)$ \\
\hline \multirow{2}{*}{ Organizational performance } & $0.249^{* *}$ & $0.249^{* *}$ & $0.248^{* *}$ & $0.259^{* *}$ & $0.243^{* *}$ & $0.250^{* *}$ \\
\hline & $(0.058)$ & $(0.058)$ & $(0.057)$ & $(0.057)$ & $(0.058)$ & $(0.057)$ \\
\hline \multirow{2}{*}{ Firm Size } & 0.050 & 0.050 & 0.054 & 0.057 & 0.042 & 0.051 \\
\hline & $(0.046)$ & $(0.045)$ & $(0.045)$ & $(0.045)$ & $(0.045)$ & $(0.045)$ \\
\hline \multirow{2}{*}{ Firm Age } & 0.086 & 0.069 & 0.073 & 0.109 & 0.111 & 0.152 \\
\hline & $(0.254)$ & $(0.251)$ & $(0.250)$ & $(0.247)$ & $(0.252)$ & $(0.248)$ \\
\hline \multirow{2}{*}{ Union } & $-0.090+$ & $-0.102^{*}$ & $-0.095^{*}$ & $-0.081+$ & $-0.101^{*}$ & $-0.090+$ \\
\hline & $(0.048)$ & $(0.048)$ & $(0.048)$ & $(0.047)$ & $(0.048)$ & $(0.047)$ \\
\hline \multirow{2}{*}{ HR Department } & -0.005 & -0.018 & -0.014 & -0.005 & -0.019 & -0.012 \\
\hline & $(0.028)$ & $(0.028)$ & $(0.028)$ & $(0.028)$ & $(0.028)$ & $(0.028)$ \\
\hline \multirow{2}{*}{ Leverage } & $-0.013^{*}$ & $-0.014^{*}$ & $-0.014^{*}$ & $-0.014^{*}$ & $-0.014^{*}$ & $-0.013^{*}$ \\
\hline & $(0.006)$ & $(0.006)$ & $(0.006)$ & $(0.006)$ & $(0.006)$ & $(0.006)$ \\
\hline \multirow{2}{*}{ Current Ratio } & 0.002 & 0.002 & 0.002 & 0.004 & 0.002 & 0.005 \\
\hline & $(0.010)$ & $(0.010)$ & $(0.010)$ & $(0.010)$ & $(0.010)$ & $(0.010)$ \\
\hline \multirow{2}{*}{ Changes in Demand Conditions } & -0.002 & -0.001 & -0.002 & -0.005 & -0.004 & -0.004 \\
\hline & $(0.010)$ & $(0.010)$ & $(0.010)$ & $(0.010)$ & $(0.010)$ & $(0.010)$ \\
\hline \multirow{2}{*}{ Organizational Commitment } & -0.028 & -0.046 & -0.040 & -0.043 & -0.041 & -0.051 \\
\hline & $(0.039)$ & $(0.039)$ & $(0.039)$ & $(0.039)$ & $(0.039)$ & $(0.039)$ \\
\hline \multirow{2}{*}{ Job Satisfaction } & -0.058 & -0.054 & -0.039 & -0.034 & -0.035 & -0.029 \\
\hline & $(0.039)$ & $(0.038)$ & $(0.040)$ & $(0.039)$ & $(0.040)$ & $(0.040)$ \\
\hline \multirow{2}{*}{ HPWS } & & $0.011^{*}$ & $0.011^{*}$ & $0.010+$ & $0.011^{*}$ & $0.010^{*}$ \\
\hline & & $(0.005)$ & $(0.005)$ & $(0.005)$ & $(0.005)$ & $(0.005)$ \\
\hline \multirow{2}{*}{ Vertical Communication } & & & -0.050 & -0.054 & & \\
\hline & & & $(0.034)$ & $(0.033)$ & & \\
\hline \multirow{2}{*}{ HPWS X Vertical Communication } & & & & $0.020^{*}$ & & \\
\hline & & & & $(0.008)$ & & \\
\hline \multirow{2}{*}{ Horizontal Communication } & & & & & -0.042 & -0.033 \\
\hline & & & & & $(0.028)$ & $(0.028)$ \\
\hline \multirow{2}{*}{ HPWS X Horizontal Communication } & & & & & & $0.020^{* *}$ \\
\hline & & & & & & $(0.008)$ \\
\hline Chi-square statistics & $5.837^{* *}$ & $5.845^{* *}$ & $5.605^{* *}$ & $5.796^{* *}$ & $5.604^{* *}$ & $5.900^{* *}$ \\
\hline Sigma_u & 0.116 & 0.116 & 0.121 & 0.135 & 0.122 & 0.140 \\
\hline Sigma_e & 0.101 & 0.100 & 0.100 & 0.098 & 0.100 & 0.098 \\
\hline Rho & 0.569 & 0.574 & 0.598 & 0.654 & 0.598 & 0.673 \\
\hline
\end{tabular}

Note. Standard errors are in parentheses. Year dummies are included.

$+p<.10,{ }^{*} p<.05,{ }^{* *} p<.01,{ }^{* * *} p<.001$, two-tailed

In hypotheses 2.1 and 2.2, we propose that internal communication moderates the HPWS-organizational performance relationship. These two moderation hypotheses are tested in models 4 and 8, respectively. All the variables in the interaction terms are mean-centered to reduce non-essential multicollinearity (Aiken \& West, 1991). In hypothesis 2.1, we predict a positive interaction effect between HPWS and vertical communication on organizational performance. Model 4 in Table 2 shows the results of this test: the estimated coefficient for the interaction between HPWS and vertical communications is positive and significant $(\beta=.020, p \leq .05)$, supporting hypothesis 2.1. Figure 1 depicts the effect of this interaction on organizational performance. We draw this graph following the steps suggested by Aiken and West (1991), and as shown, the positive effect of HPWS on organizational performance is stronger when vertical communication is high (i.e., a solid line). In addition, slope analysis confirms that the positive slope is apparent at a high level of vertical communication $(\beta=.017, p \leq .05)$ but not a low level $(\beta=.003$, n.s. $)$.

In Hypothesis 2.2, we argue that a positive interaction effect between HPWS and horizontal communication on organizational performance. In model 6 in Table 2, the estimated coefficient for the interaction between HPWS and horizontal communications is positive and significant $(\beta=.020, p \leq .01)$, indicating that the HPWS-organizational 
performance relationship varies by the level of horizontal communication. Figure 2 graphically depicts this interaction effect, and as shown, the positive effect of HPWS on organizational performance is stronger when horizontal communication is high (i.e., a solid line). Additionally, the slope test results confirm that the positive HPWS effect on performance is significant when horizontal communications is high $(\beta=.017, p \leq .01)$ but is not different from 0 when horizontal communication is relatively low $(b=.001, n . s$. $)$.

Figure 1. Moderating Effects of Bottom-up Communication

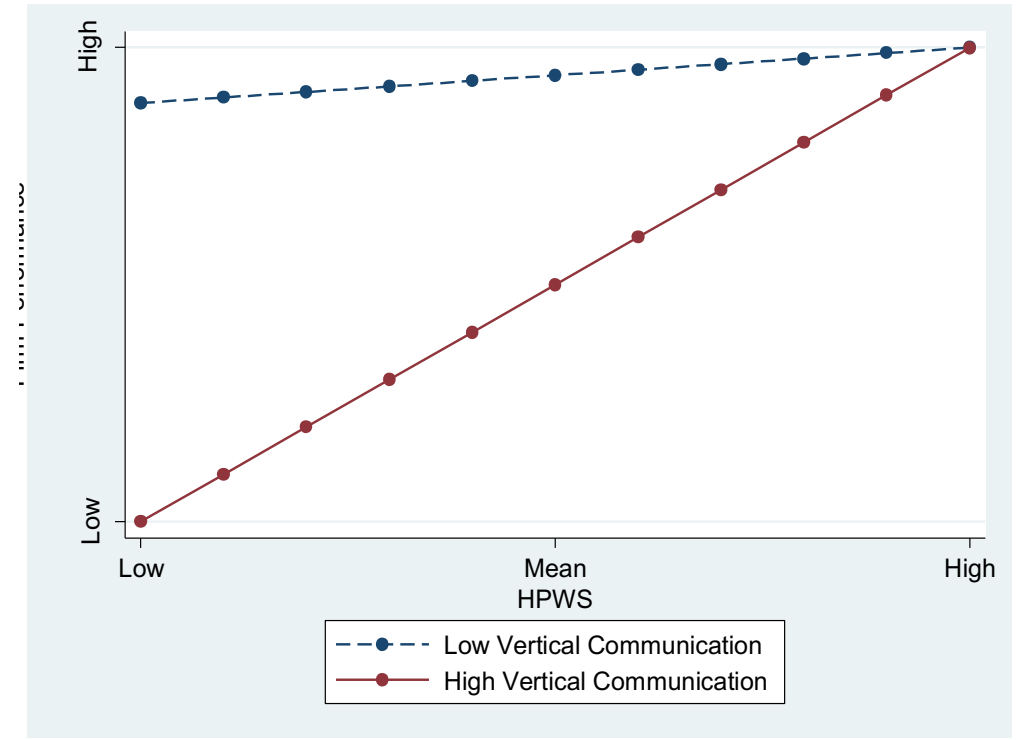

Note. This graph is derived from the results shown in Model 4 (Table 2).

Figure 2. Moderating Effects of Horizontal Communication

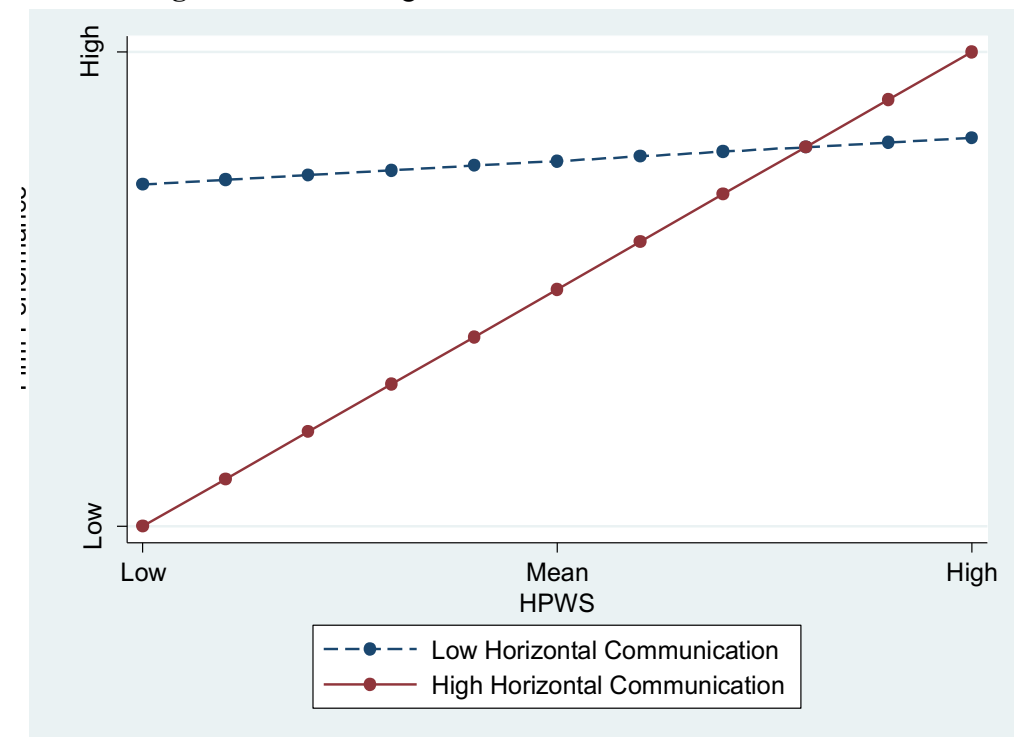

Note. This graph is derived from the results shown in Model 6 (Table 2). 


\section{DISCUSSION AND CONCLUSION}

This study is aimed at examining the role of communication within an organization in implementing HPWS. We argue that the effect of HPWS on organizational performance depends on the level of internal communication. We divide organizational communication into two types and theorize their moderating effects on the HPWSorganizational performance relationship. The results support our main argument that the positive effect of HPWS on organizational performance is strengthened by active communication within an organization. Specifically, we find that vertical and horizontal communication positively moderate the positive effect of HPWS on organizational performance. Thus, our findings imply that the degree to which HPWS and organizational performance are linked is partially a matter of internal communication.

Our study contributes to the research on HPWS and organizational communication. First, despite numerous studies, the HPWS-organizational performance relationship remains unclear (Combs, Liu, Hall, \& Ketchen, 2006). Consequently, researchers have shifted their attention to the organizational context of HPWS implementation (Becker \& Gerhart, 1996). Following these studies, we develop a theory that explains the role of communication in implementing HPWS. Our research confirms the importance of the organizational context and highlights the need for further studies on such contextual effects in implementing HPWS. Second, although a number of studies examine the effects of internal communication on employee-level outcomes, such as employee satisfaction, job performance, and perceived interpersonal and informational justice (Den Hartog et. al. 2013; Kernan \& Hanges, 2002; Madlock, 2008; Pincus, 1986), relatively little attention is paid to how internal communication affects firmlevel outcomes. Our findings shed light on the relationship between internal communication and firm performance by showing that organizational communication can be an important contextual factor in developing and implementing organization systems.

We acknowledge several limitations of our study. First, like most research on HPWS, we use the additive measure of HWPS based on the assumptions that HR practices have additive effects on organizational performance and that these practices are substitutable (Batt, 2002). This assumption might not always hold true because the marginal effect of additional HR practices can differ by HPWS level. Moreover, the substitution effect can be limited because each HR practice has a different effect on organizational performance depending on its design to enhance a certain aspect of employee behavior. Thus, future studies could categorize a wide variety of HR practices by their intended purpose and theorize the moderating effects of communication on the HPWS-organizational performance relationship, contributing to a deeper understanding of the effects of HPWS on organizational performance. Second, our study relies on secondary data from the HCCP survey to measure employees' perceptions of the effectiveness of internal communication. We find that each type of communication has distinct effects on the HPWS-organizational performance relationship, but the survey items on communication effectiveness are not designed to capture the type of information that employees exchange, so we cannot strongly assume that active internal communication actually leads to information- and knowledge-sharing activities. For instance, even with active horizontal communication, each department might not be able to share relevant information and knowledge due, for example, to misunderstandings about other departments' role and activities. Therefore, future studies that capture the extent to which employees share relevant information could more accurately assess the effects of internal communication. Finally, our sample includes only relatively large-scale manufacturing firms, which might limit the generalizability of the findings. For example, organizational communication is crucial in the firms which need to rapidly update their operational processes in response to dynamic customer needs but is less likely to be important in firms that perform highly routinized processes. Therefore, future studies should replicate and extend our model in various organizational contexts.

\section{ACKNOWLEDGMENT}

This work was supported by NRF(National Research Foundation of Korea) Grant funded by the Korean Government(NRF-2014-Fostering Core Leaders of the Future Basic Science Program/Global Ph.D. Fellowship Program). 


\section{AUTHOR BIOGRAPHIES}

Gyeonghwan Lee is a doctoral candidate at the Sogang University. His research interests include corporate governance and strategic human resource management.

Myeongju Lee (corresponding author) is a senior researcher at the Sogang University Institute for business research. Her research interests include temporary workers behavior, human resource management, and organization culture.

Younhwan Son is a doctoral candidate at the Sogang University. His research interests include employee turnover and strategic human resource management.

\section{REFERENCES}

Allen, D. G., Shore, L. M., \& Griffeth, R. W. (2003). The role of perceived organizational support and supportive human resource practices in the turnover process. Journal of Management, 6(1), 99-118.

Arthur, J. B. (1994). Effects of human resource systems on manufacturing performance and turnover. Academy of Management Journal, 37(3), 670-687.

Aiken, L. S., \& West, S. G. 1991. Multiple regression: Testing and interpreting interactions. Newbury Park, CA: Sage.

Bae, J., \& Lawler, J. J. (2000). Organizational and HRM strategies in Korea: Impact on organizational performance in an emerging economy. Academy of Management Journal, 43(3), 502-517.

Batt, R. (2002). Managing customer services: Human resource practices, quit rates, and sales growth. Academy of management Journal, 45(3), 587-597.

Becker, B., \& Gerhart, B. (1996). The impact of human resource management on organizational performance: Progress and prospects. Academy of Management Journal, 39(4), 779-801.

Bretz, R. D., \& Judge, T. A. (1994). The role of human resource systems in job applicant decision processes. Journal of Management, 20(3), 531-551.

Bowen, D. E., \& Ostroff, C. (2004). Understanding HRM-organizational performance linkages: The role of the "strength" of the HRM system. Academy of management review, 29(2), 203-221.

Boxall, P., \& Macky, K. (2007). High-performance work systems and organizational performance: Bridging theory and practice. Asia Pacific Journal of Human Resources, 45(3), 261-270.

Chadwick, C. (2010). Theoretic insights on the nature of performance synergies in human resource systems: Toward greater precision. Human Resource Management Review, 20(2), 85-101.

Chatterjee, S., Hadi, A., \& Price, B. 2000. Regression analysis by example, 3rd ed. New York: Wiley.

Cooke, W. N. (1994). Employee participation programs, group-based incentives, and company performance: A union-nonunion comparison. Industrial \& Labor Relations Review, 47(4), 594-609.

Combs, J., Liu, Y., Hall, A., \& Ketchen, D. (2006). How much do high-performance work practices matter? A meta-analysis of their effects on organizational performance. Personnel Psychology, 59(3), 501-528.

Delery, J. E. (1998). Issues of fit in strategic human resource management: Implications for research. Human Resource Management Review, 8(3), 289-309.

Den Hartog, D. N., Boon, C., Verburg, R. M., \& Croon, M. A. (2013). HRM, communication, satisfaction, and perceived performance a cross-level test. Journal of Management, 39(6), 1637-1665.

Gong, Y., Law, K. S., Chang, S., \& Xin, K. R. (2009). Human resources management and organizational performance: The differential role of managerial affective and continuance commitment. Journal of Applied Psychology, 94(1), 263.

Greene, W. (2003). Econometric analysis (5th ed.), Englewood Cliffs, NJ: Prentice Hall.

Hausman, J. A., \& Taylor, W. E. (1981). Panel data and unobservable individual effects. Econometrica, 49(6), $1377-1398$.

Huselid, M. A. (1995). The impact of human resource management practices on turnover, productivity, and corporate financial performance. Academy of Management Journal, 38(3), 635-672.

Jiang, K., Lepak, D. P., Hu, J., \& Baer, J. C. (2012). How does human resource management influence organizational outcomes? A meta-analytic investigation of mediating mechanisms. Academy of Management Journal, 55(6), 1264-1294.

Kernan, M. C., \& Hanges, P. J. (2002). Survivor reactions to reorganization: Antecedents and consequences of procedural, interpersonal, and informational justice. Journal of Applied Psychology, 87(5), 916-928.

Lau, C. M., \& Ngo, H. Y. (2004). The HR system, organizational culture, and product innovation. International Business Review, 13(6), 685-703.

LeBreton, J. M., Senter, J. (2008). Answers to 20 questions about interrater reliability and interrater agreement. Organizational Research Methods, 11(4), 815-852.

Legge, K. 2005. Human resource management: Rhetorics and realities. Basingstoke, UK: Palgrave Macmillan.

Lertxundi, A., \& Landeta, J. (2011). The moderating effect of cultural context in the relation between HPWS and performance: an 
exploratory study in Spanish multinational companies. The International Journal of Human Resource Management, 22(18), 3949-3967.

Liao, H., Toya, K., Lepak, D. P., \& Hong, Y. (2009). Do they see eye to eye? Management and employee perspectives of highperformance work systems and influence processes on service quality. Journal of Applied Psychology, 94(2), 371.

MacDuffie, J. P. (1995). Human resource bundles and manufacturing performance: Organizational logic and flexible production systems in the world auto industry. Industrial \& Labor Relations Review, 48(2), 197-221.

Madlock, P. E. (2008). The link between leadership style, communicator competence, and employee satisfaction. Journal of Business Communication, 45(1), 61-78.

Nishii, L. H., \& Wright, P. (2008). Variability at multiple levels of analysis: Implications for strategic human resource management. The people make the place, 225-248.

Pincus, J. D. (1986). Communication satisfaction, job satisfaction, and job performance. Human Communication Research, 12(3), 395-419.

Robbins, S. P., \& Judge, T. A. (2013). Fundamentals of organizational behavior (15 ${ }^{\text {th }}$ ed.). Toronto: Pearson Prentice Canada.

Rodriguez, C. M. (2005). Emergence of a third culture: Shared leadership in international strategic alliances. International Marketing Review, 22(1), 67-95.

Rogers, E. M., \& Agarwala-Rogers, R. (1976). Communication in organizations. New York: Free Press.

Schermerhorn, J. R. \& Osborn, R. N. \& Uhl-Bien, M. \& Hunt, J. G. (2012). Organizational Behaviour: Experience, grow, contribute (1 $2^{\text {th }}$ ed.). New Jersey: John Wiley and Sons.

Simpson, R. L. (1959). Vertical and horizontal communication in formal organizations. Administrative Science Quarterly, 4(2), 188-196.

Snell, S. A., \& Youndt, M. A. (1995). Human resource management and organizational performance: Testing a contingency model of executive controls. Journal of Management, 21(4), 711-737.

Subramaniam, M., \& Youndt, M. A. (2005). The influence of intellectual capital on the types of innovative capabilities. Academy of Management Journal, 48(3), 450-463.

Wall, T. D., \& Wood, S. J. (2005). The romance of human resource management and business performance, and the case for big science. Human Relations, 58(4), 429-462.

Wright, P. M., Gardner, T. M., \& Moynihan, L. M. (2003). The impact of HR practices on the performance of business units. Human Resource Management Journal, 13(3), 21-36.

Wright, P. M., Gardner, T. M., Moynihan, L. M., \& Allen, M. R. 2005. The relationship between HR practices and organizational performance: Examining causal order. Personnel Psychology, 58(2), 409-446.

Wright, P. M., \& McMahan, G. C. (1992). Theoretical perspectives for strategic human resource management. Journal of Management, 18(2), 295-320.

Zatzick, C. D., \& Iverson, R. D. (2006). High-involvement management and workforce reduction: competitive advantage or disadvantage? Academy of Management Journal, 49(5), 999-1015. 


\section{NOTES}

